\title{
Feeding spectra of Arctodiaptomus salinus (Calanoida, Copepoda) using fatty acid trophic markers in seston food in two salt lakes in South Siberia (Khakasia, Russia)
}

\author{
A. P. Tolomeev $\cdot$ N. N. Sushchik $\cdot$ R. D. Gulati \\ O. N. Makhutova $\cdot$ G. S. Kalacheva $\cdot$ T. A. Zotina
}

Received: 20 May 2009/Accepted: 16 June 2010/Published online: 6 July 2010

(C) Springer Science+Business Media B.V. 2010

\begin{abstract}
During two vegetation seasons (20042005), we compared feeding spectra of Arctodiaptomus salinus (Calanoida, Copepoda) populations inhabiting two neighboring salt lakes, Shira and Shunet, Khakasia, Russia, using fatty acid (FA) trophic markers. Sestonic FA composition in two lakes moderately differed, whereas levels of diatom FA markers were higher in Lake Shunet and of Cyanobacteria and green algae markers in Lake Shira. In general, markers in storage lipids - triacylglycerols (TAG) of A. salinusreflected the differences in sestonic composition of the two lakes. Nevertheless, TAG fraction was also enriched by FA trophic markers of the minor components of seston, which were selectively ingested by the
\end{abstract}

Handling Editor: R. D. Gulati.

A. P. Tolomeev $(\bowtie) \cdot$ N. N. Sushchik .

O. N. Makhutova - G. S. Kalacheva · T. A. Zotina Institute of Biophysics of Siberian Branch of Russian Academy of Sciences, Akademgorodok, 660036

Krasnoyarsk, Russia

e-mail: tolomeev@ibp.ru

A. P. Tolomeev - N. N. Sushchik - O. N. Makhutova ·

G. S. Kalacheva - T. A. Zotina

Siberian Federal University, Svobodny av. 79, 660041

Krasnoyarsk, Russia

R. D. Gulati

Netherlands Institute of Ecology, Department of Aquatic Ecology, Rijksstraatweg 6, 3631 AC Nieuwersluis,

The Netherlands animals. In Lake Shira, A. salinus had significantly higher concentrations of bacterial FA markers in TAG. In Lake Shunet, TAG of A. salinus contained significantly higher relative amounts of 18:4 $13,18: 5 \omega 3$ and C22 polyunsaturated fatty acids (PUFA), which indicated marked contribution of cryptophytes or (and) flagellates into the diet. Laboratory experiments showed feeding on Cryptomonas and sulfur purple bacteria in Lake Shunet and ciliates and colonial picoplankton in both lakes, and generally confirmed the differences in FA trophic markers in A. salinus between the lakes. The two populations of A. salinus markedly differed in levels of essential long-chain PUFA, eicosapentaenoic (EPA) and docosahexaenoic (DHA) acids, although the levels of these FA in seston were quite similar between the two lakes. The higher levels of the essential $\omega 3$ PUFA in A. salinus in Lake Shunet may be an adaptive response of the animals to a vertical stratification of physico-chemical conditions and significantly higher salinity levels at the boundary of adjacent bottom layer in this lake.

Keywords Brackish lakes .

Arctodiaptomus salinus · Fatty acids .

Feeding spectra $\cdot$ Salinity adaptation

\section{Introduction}

Calanoid copepods often dominate or co-dominate the zooplankton community in both fresh- and saline 
water ecosystems (Wen and Zhi-hui 1999; Jersabek et al. 2001; Swadling et al. 2001; Torke 2001; Tolomeyev 2002; Guerrero et al. 2006). In contrast to cladocera and rotifers, copepods have a higher average age and are slow-growing organisms with relatively low reproductive output (e.g. Sommer and Stibor 2002). To compete with the fast-growing species, they have to either occupy different food niche or to use various trade-offs between the limited food resources and extreme physico-chemical environmental conditions. The dominance of Arctodiaptomus salinus in the zooplankton of two Khakasian saline lakes Shira and Shunet (Siberia, Russia) can be considered as an example of the adaptation of copepods to the severe environment conditions. In general, this species is common in saline lakes all over the world, presumably due to its greater salinity tolerance (Guerrero et al. 2006, 2007). The phytoplankton in both lakes is dominated by cyanobacterial species, including a majority of picoplankton forms (Quesada et al. 2002; Degermendzhy et al. 2003) that obviously cannot be considered as an important food source for these calanoids that are adapted to filterfeed on coarse food particles (Kleppel 1993; Sommer and Sommer 2006). However, several physiological and ecological traits of the copepod can provide clues to the understanding of strategies adapted by these calanoids. The filtering rates of copepods in the cold and saline waters, i.e. water of high density, are obviously higher than those of Cladocera and Rotifera. Hence, the calanoids can benefit at low total concentration of food, even though the consumption of small-size particles is much less efficient (Hansen et al. 1994; Bern 1994). Selective feeding based on taste discrimination allows calanoid copepods to avoid undesired food, often of low nutrition quality or toxic species (DeMott 1991; Kurmayer and Juttner 1999). Thus, they can optimize the intake of valuable food even when it is present in the environment in a low concentration. It is known that copepods can withstand periods of food deficiency (summer phytoplankton depression or winter low production) due to accumulated energy reserves in the form of triacylglycerols (TAG) or wax esters (Hagen and Auel 2001). In addition, specific accumulation of PUFAs may be responsible for maintaining cell membrane fluidity at low temperatures (the so-called homeoviscous adaptation), which allows copepods to remain active during the winter and, as a result, to prolong generation time and life cycle (Kattner et al. 2007; Smyntek et al. 2008; Brett et al. 2009).

Studies on the nutritional requirements and feeding behavior of copepods are highly necessary to understand degree and ways of their adaptation to the given environment. The direct microscopic analysis of gut contents of zooplankton are often constrained by two reasons: (1) some ingested food particles found in the gut are there because they are not assimilated (Porter 1975) so that the presence of food in the gut can present a biased picture; (2) in contrast, some of the phytoplankton species ingested can be easily and quickly digested and thus may not be detected in the gut (Knisley and Geller 1986). Thus, in recent decades, biochemical markers, namely fatty acids, have been widely used to estimate sources and flows of organic matter in various ecosystems and assimilated food items in the biomass of aquatic consumers (Napolitano 1999; Rooker et al. 2006; El-Sabaawi et al. 2009). Most zooplankton species are considered to have weak ability to synthesize fatty acyl groups of their lipids and, hence, have to obtain most part of fatty acids with the food (Goulden and Place 1990; Brett et al. 2006). Meanwhile, the accumulation of storage lipids is sufficient in some zooplankton species, especially in copepods (Hagen and Auel 2001). It has been considered that bulk of fatty acyl chains in TAG originate from food and can reflect the composition of their food consumed during the preceding 3-4 weeks (Bourder and Amblard 1989; Desvilettes et al. 1997).

During this study, our aim was to identify and compare the actual food sources for A. salinus in two neighboring saline lakes that contrasted in hydrophysical and chemical conditions as well as in their plankton species composition. We used two approaches to identify the original diet of the copepods. First, we analyzed fatty acid biomarkers in seston and animals in the lakes, and second, we carried out feeding experiments to show the groups and species of microorganisms that were consumed. We addressed four main questions in order to outline how plastic are the calanoid copepod in adapting to biochemical of their food: (1) How and to what extent the fatty acids of A. salinus reflect the fatty acid composition of their seston food? (2) How comparable are the fatty acid levels of $A$. salinus between the lakes? (3) Do the differences in feeding spectra explain the variability of fatty acid composition in 
copepod populations in the lakes? and (4) Do the different salinity conditions of two lakes explain, at least partly, the variations in fatty acid composition of the two populations of $A$. salinus?

\section{Study site}

We carried out the study in two neighboring saline, meromictic lakes Shira and Shunet located in the Republic of Khakasia, Russia. Lakes are situated in steppe zone, which is characterized by a sharply continental climate. Lakes have ice-free period for about 6 months of the year.

Lake Shira $\left(54^{\circ} 30^{\prime} \mathrm{N}\right.$ and $90^{\circ} 14^{\prime} \mathrm{E} ; 354 \mathrm{~m}$ above sea level) has a surface area $34.5 \mathrm{~km}^{2}$, mean depth$11.2 \mathrm{~m}$, maximum depth-23.3 $\mathrm{m}$. The salinity ranged from 11.5 to $14.5 \mathrm{~g} \mathrm{l}^{-1}$ over the depth with the decrease up to $9.5 \mathrm{~g} \mathrm{l}^{-1}$ in surface layers in May after the ice melting. The only small river that flows into the lake accounts for $80 \%$ of the lake's total annual inflow. The main ecological features of Lake Shira are given elsewhere (Degermendzhy and Gulati 2002; Gulati et al. this volume). Briefly, in the summer period the stratification thermocline is located at the depth about $6 \mathrm{~m}$ and average depth of chemocline zone is about $13 \mathrm{~m}$. Arctodiaoptomus salinus is the only dominant crustacean present throughout the year in the zooplankton (Zadereev and Tolomeyev 2007). In summer, the biomass of A. salinus is about $20 \mathrm{~g} \mathrm{~m}^{-2}$. In July, the rotifers Brachionus plicatilis and Hexarthra oxiuris develop large populations, reaching up to $50 \%$ of total zooplankton biomass. During the stratification period, A. salinus has a bimodal vertical distribution with a slight decrease in abundance in the metalimnion (Zadereev and Tolomeyev 2007). The distribution of zooplankton in deeper layers is limited by the anoxic zone at $14-15 \mathrm{~m}$. The phytoplankton community in Lake Shira is dominated by Cyanobacteria Lyngbya contorta and by several Aphanothece morphotypes. The "microbial loop" comprises heterotrophic nanoflagellates (up to 10 thousand cells $\mathrm{ml}^{-1}$ ), ciliates Strombidium sp. and Cyclidium sp., and photosynthetic bacteria Amoebobacter purpurea in the chemocline zone.

Lake Shunet $\left(54^{\circ} 36^{\prime} \mathrm{N}\right.$ and $\left.90^{\circ} 20^{\prime} \mathrm{S}\right)$ is also of internal drainage, its surface area is $0.47 \mathrm{~km}^{2}$, maximum depth is $6.2 \mathrm{~m}$ and anoxic zone starts below $5.2 \mathrm{~m}$. The salinity of the water from surface to the depth of $4 \mathrm{~m}$ ranges from 14.4 to $19.2 \mathrm{~g} \mathrm{l}^{-1}$; it sharply increases up to $40 \mathrm{~g} \mathrm{l}^{-1}$ at $5 \mathrm{~m}$ and exceeds $60 \mathrm{~g}^{-1}$ near the bottom. A. salinus also dominates in zooplankton with the summer biomass of 2.5$4.0 \mathrm{~g} \mathrm{~m}^{-3}$ with the density of $60-150$ ind. $1^{-1}$. Three rotifer genera, Keratella, Hexarthra and Brachionus, also occur in zooplankton community.

The taxonomic composition of phytoplankton of Lake Shunet was evaluated only in July 2002 when picoplankton Cyanobacteria Synechocystis sp. up to $60 \%\left(0.12 \mathrm{mg} \mathrm{l}^{-1}\right)$ of total phytoplankton biomass dominated the phytoplankton community (Degermendzhy et al. 2003). Cyclotella sp., a diatom, reached up to $\left(0.06 \mathrm{mg} \mathrm{l}^{-1}\right)$, i.e. $30 \%$ of total phytoplankton biomass. Green algae dominated by Dictyosphaerium tetrachotomum comprised only $10 \%\left(0.03 \mathrm{mg} \mathrm{l}^{-1}\right)$ of total phytoplankton biomass. Purple and green phototrophic bacteria were highly abundant (their total density $-10^{8}$ cells $\mathrm{ml}^{-1}$ ) and formed a thin layer of about $5 \mathrm{~cm}$ in the chemocline zone (Rogozin et al. 2005). A diverse microorganism community, comprising ciliates Strombidium and Cyclidium spp., and autotrophic flagellates Cryptomonas sp. (up to $25 * 10^{4}$ cells $1^{-1}$ ) was found above this layer at depth of $5.0-5.2 \mathrm{~m}$.

\section{Methods}

\section{Sampling}

In both lakes, we sampled during June and July in both 2004 and 2005. Seston in Lake Shira was sampled with a 6-L Ruttner-like sampler from the depths of 3 and $9 \mathrm{~m}$ that corresponded to the mean depths of epilimnion and oxygenic hypolimnion zones, respectively. Hypolimnion of Lake Shunet (depth lower than $5 \mathrm{~m}$ ) was anoxic in June and July of both years, with a complete absence of zooplankton. Hence, we sampled only from the epilimnion (mean depth $2.5 \mathrm{~m}$ ). The samples were prescreened through $115-\mu \mathrm{m}$ nylon mesh to remove the most large zooplankton organisms. For fatty acid analyses, seston was collected from 400-600 ml sub-samples by vacuum filtration onto membrane filters (Vladipor, pore size $0.75-0.85 \mu \mathrm{m}$ ), precovered with a layer of $\mathrm{BaSO}_{4}$ to facilitate the separation of residues. The 
filters were dried at $35^{\circ} \mathrm{C}$ within an hour, and the residue was then separated from filters and placed into chloroform-methanol mixture $(2: 1, \mathrm{v} / \mathrm{v})$ and frozen.

Zooplankton was sampled with closing plankton net of $115-\mu \mathrm{m}$ nylon mesh. In Lake Shira, net was hauled from $5 \mathrm{~m}$ to surface and from 10 to $7 \mathrm{~m}$ to cover the epilimnion and hypolimnion, respectively. In Lake Shunet, the net was hauled from $5 \mathrm{~m}$ to surface to cover whole epilimnion zone in one stretch. The zooplankton samples were washed several times with filtered $(0.7-0.8-\mu \mathrm{m}$ pore size filter) lake water, and live animals were allowed to swim in this filtered water for several hours to empty their guts. Microscopical analysis showed that the collected zooplankton mainly comprised A. salinus, and other crustaceans and rotifers were a small component (ca. $7-12 \%$ of total biovolume). The animals were then collected onto a sieve mesh and placed on filter paper for a short while to wipe of surface moisture; they were then transferred into the chloroform-methanol mixture and frozen until the further biochemical analyses.

Biochemical analyses of seston and Arctodiaptomus

The procedure for lipid analyses of seston and hydrobionts' biomass is described in detail elsewhere (Sushchik et al. 2003b; Makhutova and Khromechek 2008). Briefly, lipids from seston and Arctodiaptomus biomass were extracted by chloroform-methanol $(2: 1, \mathrm{v} / \mathrm{v})$ three times. To analyze the fatty acid composition of total lipids, part of the total lipid extract was methylated (see description below). Another part of the lipid extract was fractionated by thin-layer chromatography (TLC) on silica gel G with a solvent system for neutral lipids, as described by Sushchik et al. (2003b). The lipid fraction containing triacylglycerols was scrapped from the silica gel plate (see Fig. 1), and the solvent was evaporated before methylation. The methyl esters of fatty acids (FAMEs) of total lipids and of the triacylglycerols were prepared in a mixture of methanol-sulfuric acid $(20: 1, \mathrm{v} / \mathrm{v})$ at $90^{\circ} \mathrm{C}$ during $2 \mathrm{~h}$. FAMEs were analyzed and identified on a gas chromatograph equipped with a mass spectrometer detector (GCD Plus, HewlettPackard, USA) using a capillary HP-FFAP column as described by Sushchik et al. (2004).

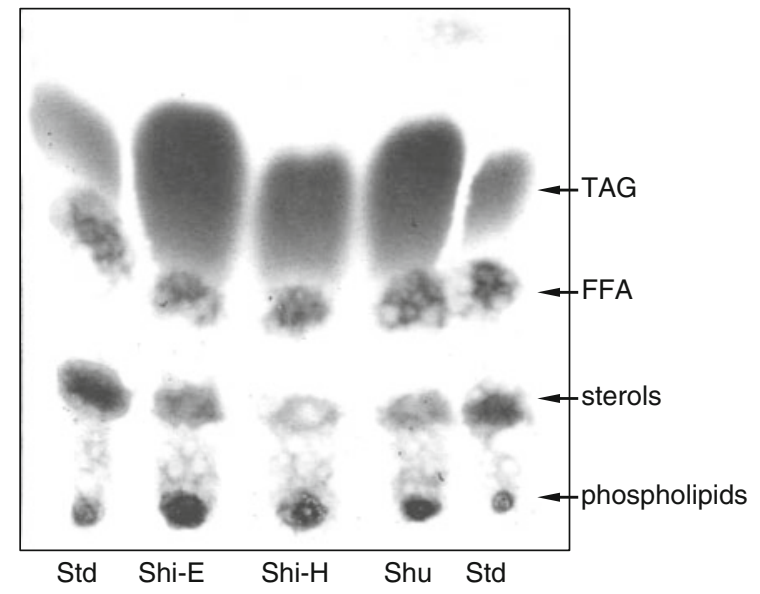

Fig. 1 Qualitative thin-layer chromatogram of lipids from A. salunis biomass collected in epilimnion (Shi-E) and hypolimnion $(S h i-H)$ of Shira and Shunet $(S h u)$ lakes (Khakasia, Russia). Std standard reference mixture, FFA free fatty acids

Feeding experiments

Experiments were aimed to find out the feeding selectivity of $A$. salinus on plankton organisms in the investigated lakes. While FATM approach differentiates food resources between large microbial groups, the direct measurements allow identifying the species consumed. The study allows interpreting the FATM sources in the animal's food. For instance, domination of picoplankton Cyanobacteria in seston and finding the cyanobacterial markers in zooplanktors does not necessarily infer the feeding on them. If these species are not consumed (due to small size), the cyanobacterial markers in zooplanktors may originate from non-dominating but large species or they were accumulated formerly.

Feeding of A. salinus on natural seston of the lakes Shira and Shunet was conducted in the laboratory using the flow-through method (Gladyshev et al. 1999). Three paired glass chambers of $50 \mathrm{ml}$ each with continuously pumped-through lake water were used to find out feeding selection on phytoplankton and protozoa species (Fig. 2). Each experimental chamber contained 50-60 individuals of A. salinus, while the controls contained no animals. Chambers have a removable bottom made of net with $80-\mu \mathrm{m}$ mesh to prevent the zooplankton from escaping the chamber and to assist in transferring the animals into the chamber at the start of the experiment. Viscosity of surface film formed on the net bottom prevents the 


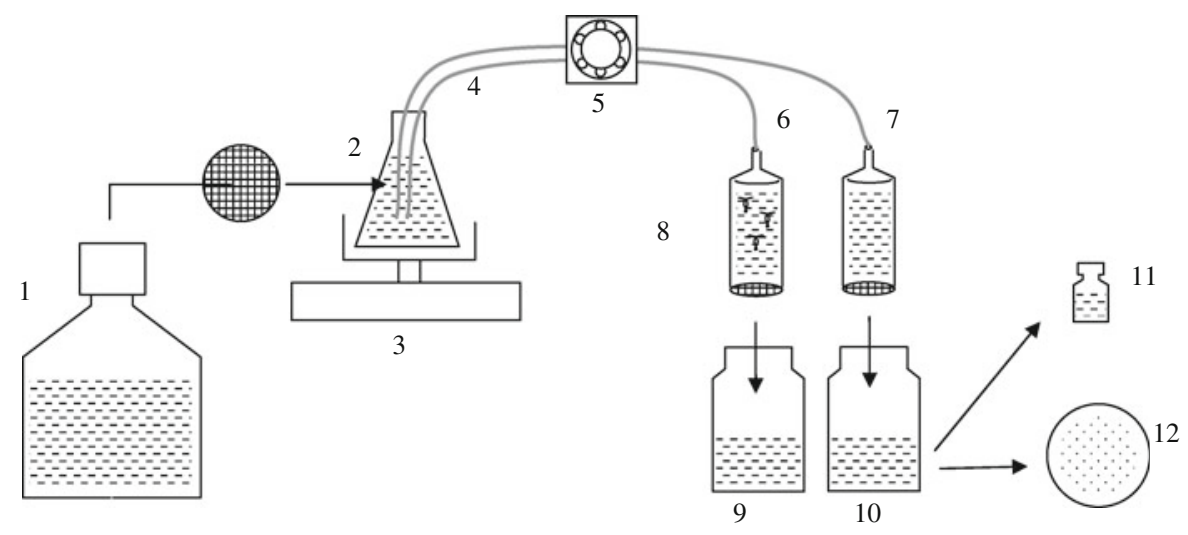

Fig. 2 The scheme of flow-through method (modified from Gladyshev et al. 1999). 1 Lake water taken from $5,5.2 \mathrm{~m}$ in Lake Shunet and from $12 \mathrm{~m}$ in Lake Shira for three experiments, 2 feeding water filtered from zooplankton through net (mesh size $80 \mu \mathrm{m}), 3$ shaker, 4 connecting tubes, 5 peristaltic pump, 6, 7 experimental and control chambers with the net bottoms. Viscosity of surface film formed on the net

uncontrolled water flow, but allows only the flow driven by a peristaltic pump. After passing the chambers, the water with seston particles flows into collecting vessels wherein the seston was fixed immediately with Lugol's solution, to prevent changes in cells number due to either growth or lysis. Flow rate of the water was $200 \mathrm{ml} \mathrm{day}^{-1}$.

Lake seston used in experiments was taken from 5.0- to 5.2-m stratum in Lake Shunet and from $12 \mathrm{~m}$ in Lake Shira. These strata in the two lakes, respectively, had very diverse species composition of microorganisms, observed during preliminary microscopic analysis. In the first of two experiments conducted with the seston of Lake Shunet, we used the water from $5.0 \mathrm{~m}$ depth, where ciliates and flagellates were abundant; the second experiment was conducted with seston from $5.2 \mathrm{~m}$ depth, and $10 \times$ diluted with lake water from $3 \mathrm{~m}$. The objective of this experiment was to measure feeding of $A$. salinus on sulfur purple bacteria. This resource might be important for calanoids in meromictic lakes as it has been reported by Overmann et al. (1999). We did not use natural concentrations of bacteria because of their very high density. However, preliminary observations revealed that the calanoids can exploit this food resource by either migrating into the "purple layer" for a short time or when bacteria are brought into the upper layers due to turbulence. Feeding of $A$. salinus in Lake Shira was studied using seston from $12 \mathrm{~m}$, as bottom prevents the water from running out entirely but allows the dosed flow, 8 copepods, 9, 10 experimental and control collecting vessels with fixing Lugol's solution, 11 10-ml sample for protozoa counting, $1250-\mathrm{ml}$ sample filtered through the membrane filter for phytoplankton counting under epifluorescent microscope

done previously on the seston from epilimnion zone by Tolomeyev (2002).

Experiments lasted 3 days, and samples for phytoplankton and protozoa counting $(50$ and $10 \mathrm{ml}$, respectively) were taken daily. Seston was concentrated on the membrane filters (Vladipor, pore size $0.75-0.85 \mu \mathrm{m})$ by filtration. Algae on filters were counted under epifluorescent microscope Axioscop 40 (Carl Zeiss). Protozoa organisms were counted in a Fuchs-Rosenthal chamber without the concentrating treatment. During the experiment, the lake water in the feed vessel was refreshed daily.

If the density of the certain species considerably decreased in the experimental chambers compared with the controls, this decrease was assumed to be caused by their consumption by A. salinus. For each consumed species, daily ration was calculated as the mean of rations obtained each day during 3-day experiment. Daily ration was calculated as follows:

$R=(\mathrm{Nc}-\mathrm{Ne}) \cdot w \cdot F / B$,

where $\mathrm{Nc}$ and $\mathrm{Ne}$ are concentrations of the food items (cells $\mathrm{ml}^{-1}$ ) in control and experimental collecting vessels, respectively; $w$ is mean wet weight of food cells $(\mathrm{mg})$ calculated from biovolume using the conversion factor of 1.0 (e.g. Gosselain et al. 2000), $F$-daily flow volume $(\mathrm{ml}), B$-total wet biomass (mg) of A. salinus in the experimental chamber. 
Standard and multivariate statistics

Student's $t$-test and paired $t$-test were carried out conventionally to compare FA profiles of seston and Arctodiaptomus in two lakes. Principal component analysis (PCA) using Canoco software, version 4.5 (Leps and Smilauer 2003) was performed to elucidate main factors contributing in variability of FA composition of the animals.

\section{Results}

Fatty acids in seston

A total of 43 fatty acids were identified in all seston samples from both lakes, and levels of main FA are given in Table 1. In general, levels of saturated and monounsaturated acids were slightly higher in Lake Shunet than those in Lake Shira. FA percentages in seston of the upper and lower layers in Lake Shira were quite different: levels of PUFA fraction in the upper layer were smaller than those of saturated acids. The vertical distribution of sestonic fatty acids in Lake Shira had been earlier recorded (in 2001), and appreciable variation in most prominent fatty acids, e.g., saturated FA, 16: $\omega 7$ and 18:3 $\omega 3$, with the depth had been found (Fig. 3). In Lake Shira, epilimnion and hypolimnion layers were almost equal in their size, while in Lake Shunet the epilimnion zone was rather thick and comprised most part of water column. Therefore, we used different sampling procedures for seston samples in these two lakes (see "Methods"). For comparing the

Table 1 Fatty acid composition (\% of the total) of seston in lakes Shira and Shunet (Khakasia, Russia), 2005

\begin{tabular}{|c|c|c|c|c|c|c|c|c|c|c|}
\hline \multirow{2}{*}{ FA } & \multicolumn{4}{|l|}{ Shira } & \multicolumn{6}{|l|}{ Shunet } \\
\hline & $\begin{array}{l}30 \text { Jun } \\
3 \mathrm{~m}\end{array}$ & $\begin{array}{l}30 \text { Jun } \\
9 \mathrm{~m}\end{array}$ & $\begin{array}{l}10 \mathrm{Jul} \\
3 \mathrm{~m}\end{array}$ & $\begin{array}{l}10 \mathrm{Jul} \\
9 \mathrm{~m}\end{array}$ & $\begin{array}{l}2 \mathrm{Jul} \\
2.5 \mathrm{~m}\end{array}$ & $\begin{array}{l}2 \mathrm{Jul} \\
2.5 \mathrm{~m}\end{array}$ & $\begin{array}{l}2 \mathrm{Jul} \\
2.5 \mathrm{~m}\end{array}$ & $\begin{array}{l}7 \mathrm{Jul} \\
2.5 \mathrm{~m}\end{array}$ & $\begin{array}{l}7 \mathrm{Jul} \\
2.5 \mathrm{~m}\end{array}$ & $\begin{array}{l}7 \mathrm{Jul} \\
2.5 \mathrm{~m}\end{array}$ \\
\hline $14: 0$ & 8.4 & 7.2 & 6.1 & 6.8 & 12.5 & 12.6 & 13.0 & 17.2 & 8.6 & 13.5 \\
\hline $16: 0$ & 30.3 & 25.4 & 32.0 & 27.3 & 32.4 & 26.5 & 31.2 & 26.8 & 30.3 & 25.4 \\
\hline 18:0 & 14.4 & 8.3 & 21.3 & 13.5 & 8.7 & 13.3 & 8.7 & 8.8 & 30.5 & 11.1 \\
\hline Other SAFA & 5.6 & 4.5 & 16.1 & 3.6 & 4.0 & 1.7 & 3.0 & 2.8 & 1.8 & 2.9 \\
\hline Total SAFA & 58.7 & 45.4 & 75.5 & 51.2 & 57.6 & 54.1 & 55.9 & 55.6 & 71.2 & 52.9 \\
\hline Total BFA & 4.0 & 3.9 & 2.5 & 1.7 & 1.4 & 1.5 & 0.8 & 3.6 & 1.5 & 3.8 \\
\hline $16: 1 \omega 7$ & 8.7 & 9.3 & 5.5 & 7.7 & 12.1 & 15.1 & 14.1 & 18.6 & 11.1 & 14.3 \\
\hline $18: 1 \omega 9$ & 14.3 & 12.0 & 8.7 & 17.5 & 16.7 & 14.7 & 16.0 & 12.5 & 10.2 & 14.5 \\
\hline Other MUFA & 3.2 & 4.9 & 3.8 & 2.6 & 4.0 & 5.9 & 5.6 & 5.0 & 2.2 & 4.2 \\
\hline Total MUFA & 26.2 & 26.2 & 18.0 & 27.8 & 32.8 & 35.7 & 35.7 & 36.1 & 23.5 & 33.0 \\
\hline $16: 2 \omega 6$ & ND & 0.1 & ND & ND & ND & ND & 1.3 & ND & ND & ND \\
\hline $16: 2 \omega 4$ & 1.3 & 1.5 & ND & 1.5 & 1.6 & 1.3 & ND & 0.2 & 0.3 & 0.6 \\
\hline $16: 3 \omega 3$ & 1.2 & 1.9 & ND & 2.1 & ND & ND & ND & ND & 0.1 & 0.3 \\
\hline $18: 2 \omega 6$ & 2.3 & 3.1 & 1.6 & 2.9 & 2.2 & 2.5 & 2.2 & 1.4 & 1.1 & 2.1 \\
\hline $18: 3 \omega 3$ & 3.6 & 7.3 & 2.4 & 6.0 & 1.7 & 1.0 & 1.6 & 1.1 & 0.7 & 1.5 \\
\hline $18: 4 \omega 3$ & ND & 1.3 & ND & 1.3 & ND & 1.1 & ND & ND & 0.3 & 1.8 \\
\hline $20: 4 \omega 6$ & 0.1 & 0.2 & ND & ND & ND & ND & ND & ND & ND & ND \\
\hline $20: 3 \omega 3$ & 0.1 & 0.4 & ND & 0.5 & ND & ND & ND & ND & ND & ND \\
\hline $20: 4 \omega 3$ & 0.2 & 0.5 & ND & 0.3 & 0.3 & 0.1 & 0.3 & ND & ND & 0.3 \\
\hline $20: 5 \omega 3$ & 1.6 & 5.1 & ND & 3.4 & 1.4 & 1.1 & 1.3 & 1.4 & 0.8 & 1.9 \\
\hline $22: 5 \omega 3$ & 0.0 & 0.4 & ND & ND & ND & ND & ND & ND & ND & ND \\
\hline $22: 6 \omega 3$ & 0.3 & 1.3 & ND & 0.5 & 0.7 & 1.1 & 0.3 & ND & 0.2 & 0.7 \\
\hline Total PUFA & 10.7 & 23.1 & 4.0 & 18.5 & 7.9 & 8.2 & 7.0 & 4.1 & 3.5 & 9.2 \\
\hline
\end{tabular}

SAFA saturated fatty acids, $B F A$ branched fatty acids (include i14:0, i15:0, ai15:0, i16:0, i17:0, ai17:0), $M U F A$ monounsaturated fatty acids, $P U F A$ polyunsaturated fatty acids, $N D$ not detected 

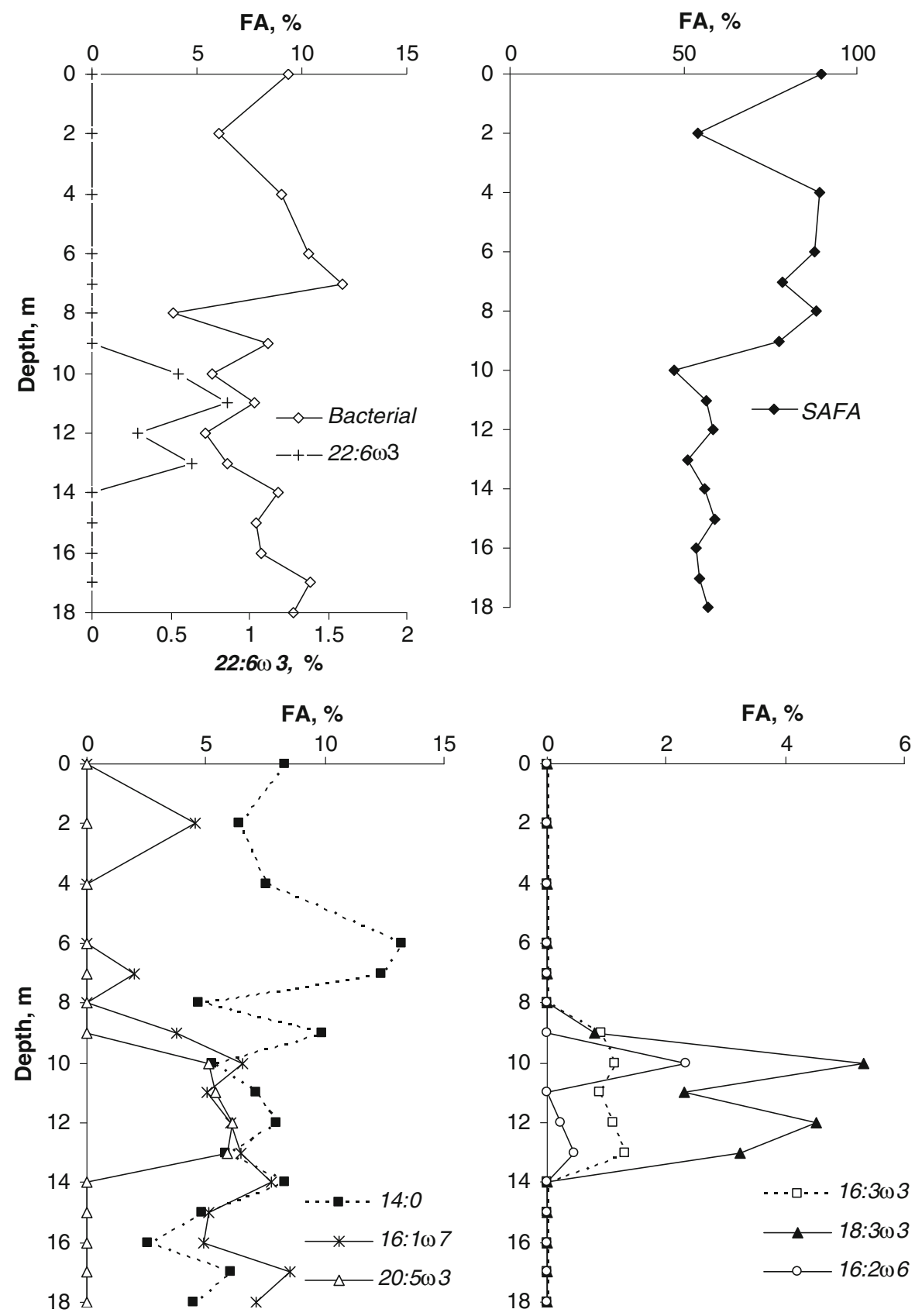

Fig. 3 Depth distribution of seston fatty acid markers (\% of the total) in Lake Shira (Khakasia, Russia), 2001, August. SAFA saturated fatty acids, bacterial sum of branched and straight odd-numbered FA

main FAs in seston of the two lakes, we calculated their average fatty acid values of samples from the upper and lower layer from Lake Shira. The average values in Lake Shira were compared with those for 2.5-m samples from Lake Shunet (Fig. 4). The percentages in total FAs of some fatty acids (14:0, $16: 1 \omega 7,16: 3 \omega 3$ and 18:3 $\omega 3$ ) in seston from the two lakes significantly differed. According to biomarker approach (Napolitano 1999; Brett et al. 2009), the higher levels of FA 14:0 and 16:1 $\omega 7$ in Lake Shunet 

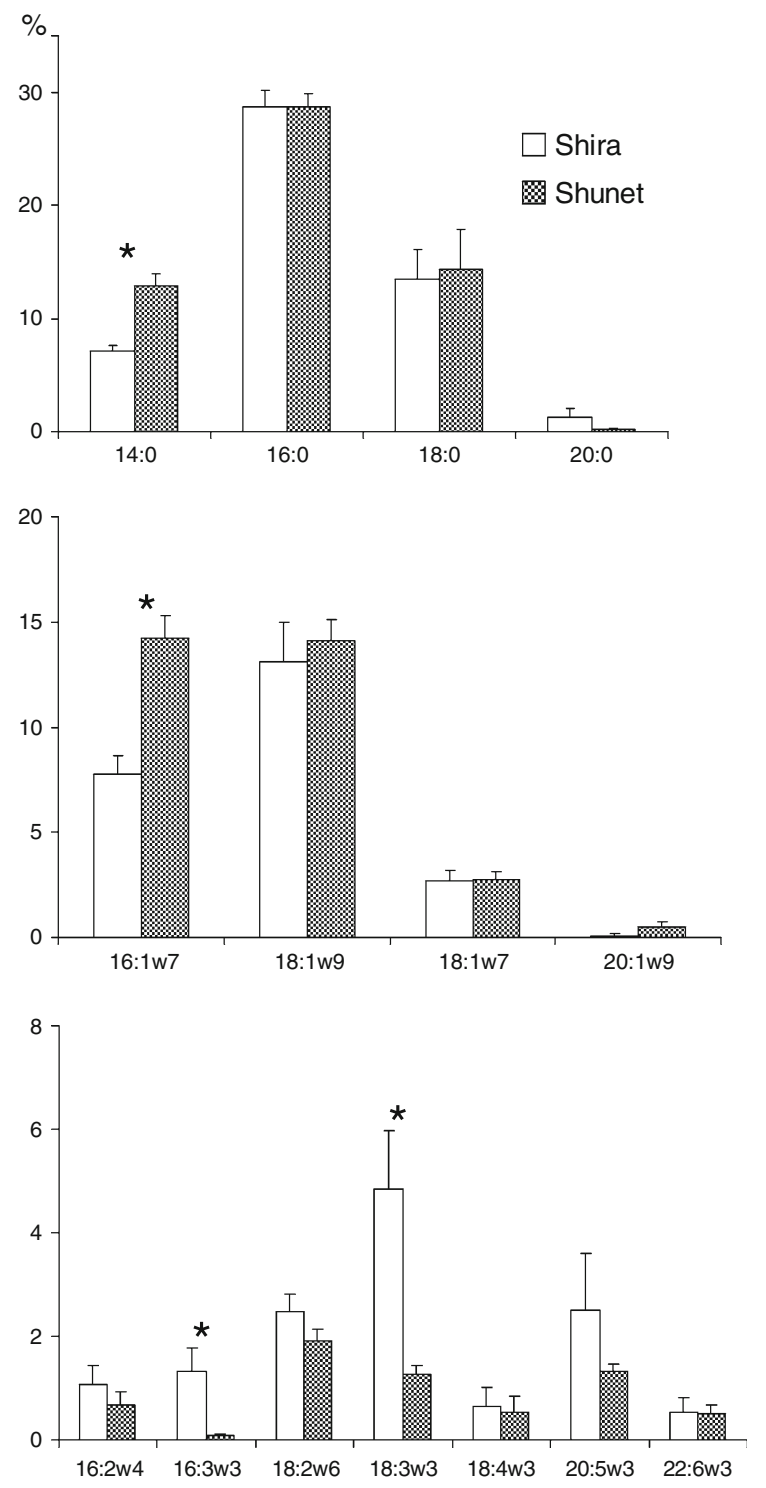

Fig. 4 Major saturated, monoenoic and polyenoic FA (\% of the total) in seston of Shira and Shunet lakes (Khakasia, Russia), 2005. The data are means of values from Table 1, bars are standard errors. Asterisks denote statistically significant differences after Student's $t$-test $(P<0.05)$

indicated higher contribution of the diatom species in seston, while the higher levels of FA 18:3 $\omega 3$ in Lake Shira were due both to Oscillatoriales and green algae in pelagic seston. Higher levels of FA 16:3 $\omega 3$ also implied greater role of green algae in Shira. Apart from the mentioned FA, the averaged levels of other FA in seston of the lakes did not significantly differ.
Fatty acids in total lipids of A. salinus

Based on prominent fatty acids identified in samples of total lipids of A. salinus (Tables 2, 3), it is clear that fatty acid profiles of the animal body were much more diverse than those of seston in these two lakes. The animals had numerous branched C14-17 saturated and monoenoic acids and PUFAs with $\mathrm{C} 16-\mathrm{C} 22$ carbon atom chains. The dominant FA in the copepods were the same in both lakes and comprised 16:0, 18:1 $\omega 9,20: 5 \omega 3,22: 6 \omega 3$ and 16:1 $\omega 7$ (Tables 2, 3). In Lake Shira, the averages of FA levels in $A$. salinus samples of epilimnion (0-5 m) and hypolimnion $(7-10 \mathrm{~m})$ did not significantly differ during the two study years (Student's $t$-test: the smallest $P=0.072$ ) (Fig. 5). This information enabled us to pool the FA data for epilimnion and hypolimnion of Lake Shira to compare with column samples from Lake Shunet. The mean percentages of the most essential PUFA in A. salinus differed significantly between the populations of this calanoid inhabiting these neighboring lakes (Student's $t$-test ranged from 2.8 to $4.6, P<0.05, v=18$ ) (Fig. 6). A. salinus in Lake Shira contained more 18:3 $\omega 3$, but the population of this calanoid in Lake Shunet was richer in 18:2 $\omega 6,18: 4 \omega 3,20: 5 \omega 3$ (eicosapentaenoic, EPA)

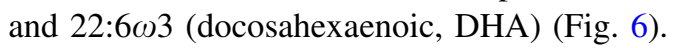

Fatty acids in triacylglycerols of A. salinus

Thin-layer chromatography of lipids of A. salinus from both lakes showed strong dominance of triacylglycerols (Fig. 1). Polar lipids, mainly phospholipids, sterols and free fatty acids were also prominent. Wax esters were in negligible amounts.

Fatty acid profiles of triacylglycerols were the similar to those of total lipids. The percentage of several FAs, however, changed to some degree (Fig. 7). In the Shira's population, the TAG fraction was slightly richer in $\omega 6$ and $\omega 3 \mathrm{C} 18$ PUFA and lower in C22 PUFA compared with the total lipids. In Lake Shunet, TAG and total lipids differed markedly. The average FA percentages of 14:0, 16:1 107 and

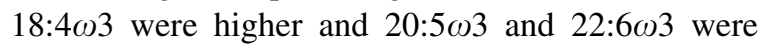
lower in TAG fraction than those in total lipids (Tables 2, 3; Figs. 6, 7).

Mean percentage values of 21 FA of TAG fraction differed significantly between the populations from the lakes (Student's $t$-test ranged from 2.7 to 8.5 , 
Table 2 Prominent fatty acids (\% of the total) in total lipids of bodies of A. salinus, collected in Lake Shira (Khakasia, Russia) in 2004-2005

\begin{tabular}{|c|c|c|c|c|c|c|c|c|c|c|c|c|}
\hline \multirow[t]{2}{*}{ FA } & \multicolumn{6}{|l|}{2004} & \multicolumn{6}{|l|}{2005} \\
\hline & $\begin{array}{l}22 \text { Jun } \\
\mathrm{e}\end{array}$ & $\begin{array}{l}22 \text { Jun } \\
\mathrm{h}\end{array}$ & $\begin{array}{l}30 \text { Jun } \\
\mathrm{e}\end{array}$ & $\begin{array}{l}30 \text { Jun } \\
\mathrm{h}\end{array}$ & $\begin{array}{l}2 \mathrm{Jul} \\
\mathrm{e}\end{array}$ & $\begin{array}{l}2 \mathrm{Jul} \\
\mathrm{h}\end{array}$ & $\begin{array}{l}30 \text { Jun } \\
\mathrm{e}\end{array}$ & $\begin{array}{l}30 \text { Jun } \\
\mathrm{h}\end{array}$ & $\begin{array}{l}5 \mathrm{Jul} \\
\mathrm{e}\end{array}$ & $\begin{array}{l}5 \mathrm{Jul} \\
\mathrm{h}\end{array}$ & $\begin{array}{l}10 \mathrm{Jul} \\
\mathrm{e}\end{array}$ & $\begin{array}{l}10 \mathrm{Jul} \\
\mathrm{h}\end{array}$ \\
\hline $14: 0$ & 8.7 & 6.5 & 6.5 & 5.8 & 10.4 & 8.4 & 3.9 & 4.3 & 3.7 & 5.0 & 5.3 & 5.0 \\
\hline $16: 0$ & 28.9 & 27.7 & 24.9 & 23.2 & 30.3 & 25.4 & 15.2 & 14.8 & 14.6 & 15.8 & 20.7 & 17.7 \\
\hline $18: 0$ & 3.7 & 5.8 & 7.1 & 2.9 & 5.1 & 4.3 & 3.7 & 1.9 & 3.5 & 3.5 & 7.4 & 4.3 \\
\hline Other SAFA & 4.3 & 4.4 & 3.7 & 3.0 & 4.7 & 3.3 & 3.3 & 2.4 & 2.4 & 2.4 & 2.9 & 2.1 \\
\hline Total SAFA & 45.6 & 44.4 & 42.2 & 34.9 & 50.5 & 41.4 & 26.1 & 23.4 & 24.2 & 26.7 & 36.3 & 29.1 \\
\hline Total BFA & 8.5 & 7.3 & 7.5 & 6.2 & 8.4 & 8.0 & 5.1 & 4.5 & 3.9 & 5.4 & 6.6 & 5.2 \\
\hline $16: 1 \omega 7$ & 10.9 & 9.3 & 10.7 & 10.2 & 12.2 & 12.4 & 7.7 & 8.4 & 6.3 & 10.0 & 8.3 & 8.5 \\
\hline $18: 1 \omega 9$ & 16.9 & 15.1 & 13.1 & 17.7 & 11.3 & 12.5 & 11.6 & 10.6 & 7.9 & 9.3 & 18.0 & 13.8 \\
\hline Other MUFA & 0.6 & 0.3 & 2.7 & 1.0 & 1.7 & 1.7 & 5.1 & 5.8 & 5.6 & 6.8 & 4.2 & 3.1 \\
\hline Total MUFA & 28.4 & 24.7 & 26.5 & 28.9 & 25.2 & 26.6 & 24.4 & 24.8 & 19.8 & 26.1 & 30.5 & 25.4 \\
\hline $16: 3 \omega 3$ & 1.4 & 0.7 & 1.4 & 1.6 & 1.4 & 1.8 & 0.9 & 2.0 & 1.1 & 1.7 & ND & 2.0 \\
\hline $18: 2 \omega 6$ & 2.7 & 2.2 & 3.4 & 4.5 & 2.1 & 3.0 & 3.1 & 3.0 & 2.5 & 2.7 & 2.7 & 2.9 \\
\hline $18: 3 \omega 3$ & 4.9 & 3.0 & 5.4 & 7.2 & 3.5 & 6.0 & 5.1 & 7.6 & 5.2 & 6.5 & 7.1 & 7.1 \\
\hline $18: 4 \omega 3$ & 2.4 & 1.3 & 2.6 & 3.5 & 2.0 & 3.4 & 2.9 & 4.3 & 3.1 & 4.1 & 1.8 & 3.7 \\
\hline $20: 4 \omega 6$ & 0.3 & 0.7 & 0.7 & 0.7 & 0.4 & 0.5 & 1.5 & 1.0 & 1.7 & 1.4 & 2.0 & 2.7 \\
\hline $20: 4 \omega 3$ & 0.3 & 0.6 & 0.5 & 0.5 & 0.3 & 0.4 & 1.0 & 0.7 & 1.2 & 0.7 & 0.8 & 0.7 \\
\hline $20: 5 \omega 3$ & 3.0 & 5.6 & 4.9 & 6.4 & 2.7 & 4.7 & 9.7 & 11.7 & 12.4 & 10.5 & 4.2 & 8.7 \\
\hline $22: 5 \omega 6$ & 0.1 & 0.6 & 0.4 & 0.2 & 0.2 & 0.2 & 1.8 & 1.1 & 2.3 & 0.9 & 0.9 & 1.0 \\
\hline $22: 6 \omega 3$ & 0.5 & 6.1 & 2.1 & 2.6 & 0.9 & 1.2 & 14.5 & 10.8 & 17.8 & 9.4 & 4.4 & 8.2 \\
\hline Other PUFA & 2.0 & 2.7 & 2.2 & 2.5 & 2.2 & 2.8 & 2.9 & 3.6 & 3.2 & 3.0 & 2.3 & 2.9 \\
\hline Total PUFA & 17.6 & 23.5 & 23.6 & 29.7 & 15.7 & 24.0 & 43.4 & 45.8 & 50.5 & 40.9 & 26.2 & 39.9 \\
\hline
\end{tabular}

$e$ epilimnion $(0-5 \mathrm{~m}), h$ hypolimnion $(7-10 \mathrm{~m})$

$P<0.05, v=18$ ) (Fig. 7). TAG fraction of copepods from Lake Shira had significantly higher values of i14:0, ai15:0, 15:0, i16:0, ai17:0, 17:0, 16:2 $\omega 4$, $16: 3 \omega 3,18: 1 \omega 9,18: 3 \omega 3$ and 20:3 $\omega 3$. Hence, FA trophic markers of bacteria, green algae and Cyanobacteria were prominent in the population of Lake Shira. However, copepods from Lake Shunet contained more 14:0, 16:1 $\omega 7,18: 2 \omega 6,18: 4 \omega 3,18: 5 \omega 3$,

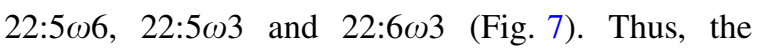
population of this latter case was rich in diatom, cryptophyte and flagellate FA trophic markers.

Similarity of FA levels in TAG fraction of A. salinus from lakes Shira and Shunet were tested by the principle component analysis (PCA). Distribution of samples is shown on the distance biplot diagram (Fig. 8). The first two principal axes accounted for $74.4 \%$ of total variation of FA. Samples from Lake Shunet were quite similar in TAG and formed two neighboring groups for the
2 years, but distinctly separated from the Lake Shira samples, which greatly varied both within the years and depth. High dissimilarity of Lake Shira samples was mainly due to pronounced variations in bacterial FA (i14:0, ai15:0, 15:0, i16:0, ai17:0, 17:0) in the epilimnion samples in 2004.

Feeding experiments

In experiments with the copepods and seston from Lake Shira, the significant decrease in density of colonial picoplankton Aphanothece in the experimental vessels compared with that in the control vessels was observed (Table 4). In the experiments with the Shunet's plankton, experimental and control vessels were differed in purple bacteria, Cryptomonas salina and Cyclidium sp. (Table 4). Thus, the consumption of these four groups of plankton of two lakes was experimentally confirmed. However, we assume that 
Table 3 Prominent fatty acids (\% of the total) in total lipids of bodies A. salinus, collected in Lake Shunet (Khakasia, Russia), 2004-2005, 0-5 m

\begin{tabular}{|c|c|c|c|c|c|c|c|c|}
\hline \multirow[t]{2}{*}{ FA } & \multicolumn{3}{|l|}{2004} & \multicolumn{5}{|l|}{2005} \\
\hline & $\begin{array}{l}29 \\
\text { Jun }\end{array}$ & $\begin{array}{l}1 \\
\text { Jul }\end{array}$ & $\begin{array}{l}1 \\
\text { Jul }\end{array}$ & $\begin{array}{l}2 \\
\text { Jul }\end{array}$ & $\begin{array}{l}2 \\
\text { Jul }\end{array}$ & $\begin{array}{l}2 \\
\text { Jul }\end{array}$ & $\begin{array}{l}7 \\
\text { Jul }\end{array}$ & $\begin{array}{l}7 \\
\text { Jul }\end{array}$ \\
\hline $14: 0$ & 6.2 & 7.5 & 4.9 & 8.0 & 7.9 & 7.8 & 7.9 & 9.4 \\
\hline $16: 0$ & 19.0 & 20.6 & 17.2 & 14.2 & 15.1 & 15.3 & 13.8 & 16.2 \\
\hline 18:0 & 4.4 & 5.4 & 4.7 & 2.8 & 2.6 & 2.4 & 2.7 & 3.0 \\
\hline $\begin{array}{l}\text { Other } \\
\text { SAFA }\end{array}$ & 3.3 & 4.1 & 3.5 & 1.6 & 1.9 & 2.0 & 2.2 & 2.7 \\
\hline Total SAFA & 32.9 & 37.6 & 30.3 & 26.6 & 27.5 & 27.5 & 26.6 & 31.3 \\
\hline Total BFA & 3.5 & 4.7 & 3.4 & 2.9 & 2.9 & 2.5 & 3.7 & 4.3 \\
\hline $16: 1 \omega 7$ & 12.2 & 13.4 & 11.7 & 8.7 & 9.1 & 9.2 & 9.0 & 9.6 \\
\hline $18: 1 \omega 9$ & 9.2 & 8.5 & 8.7 & 8.3 & 6.9 & 6.6 & 7.7 & 7.7 \\
\hline $\begin{array}{l}\text { Other } \\
\text { MUFA }\end{array}$ & 1.9 & 2.3 & 2.6 & 2.6 & 4.1 & 3.7 & 2.9 & 3.7 \\
\hline $\begin{array}{l}\text { Total } \\
\text { MUFA }\end{array}$ & 23.3 & 24.2 & 23.0 & 19.6 & 20.1 & 19.5 & 19.6 & 21.0 \\
\hline $16: 3 \omega 3$ & 0.2 & 0.2 & 0.2 & 0.4 & 0.4 & 0.4 & 0.5 & 0.5 \\
\hline $18: 2 \omega 6$ & 3.5 & 3.4 & 3.5 & 4.6 & 4.3 & 4.9 & 4.4 & 4.4 \\
\hline $18: 3 \omega 3$ & 3.2 & 3.0 & 3.3 & 4.8 & 4.6 & 5.0 & 4.5 & 4.1 \\
\hline $18: 4 \omega 3$ & 4.5 & 3.2 & 3.7 & 5.7 & 5.1 & 5.4 & 5.3 & 4.5 \\
\hline $20: 4 \omega 6$ & 1.0 & 0.8 & 1.2 & 0.9 & 1.0 & 0.8 & 1.4 & 1.3 \\
\hline $20: 4 \omega 3$ & 1.0 & 1.3 & 1.5 & 0.6 & 0.6 & 0.7 & 0.7 & 0.6 \\
\hline $20: 5 \omega 3$ & 10.7 & 9.1 & 11.8 & 9.9 & 9.8 & 10.2 & 10.2 & 8.4 \\
\hline $22: 5 \omega 6$ & 1.2 & 0.9 & 1.1 & 1.9 & 1.8 & 1.7 & 1.7 & 1.4 \\
\hline $22: 6 \omega 3$ & 11.3 & 7.8 & 12.3 & 17.1 & 16.7 & 16.7 & 16.3 & 12.3 \\
\hline $\begin{array}{l}\text { Other } \\
\text { PUFA }\end{array}$ & 3.7 & 3.6 & 4.4 & 3.6 & 3.4 & 3.1 & 3.8 & 4.0 \\
\hline Total PUFA & 40.3 & 33.3 & 43.0 & 49.5 & 47.7 & 48.9 & 48.8 & 41.5 \\
\hline
\end{tabular}

all ciliates were eaten up since no individuals were observed in the collecting vessels at the end of the experiment. The lack of significance ( $t$-statistics) was mainly due to the low density of ciliates in samples. The ability of $A$. salinus to feed on purple bacteria is explained by their aggregation in the colonies of two or four cells. Feeding on the other components of seston (heterotrophic nanoflagellates and unicellular cyanobacterial picoplankton of Synechocystis genera) was not detected in the experiments. Poor grazing on picoplankton is obviously related to their small cell size, while heterotrophic nanoflagellates may be rejected via taste discrimination. Daily rations on the consumed species, which included purple bacteria, Cryptomonas salina and Cyclidium sp., amounted to $18.7,6.2$ and $1.0 \%$ of $A$. salinus body's wet weight, respectively. The lowest Aphanothece contributed only $0.4 \%$. The total rations of copepods in the lakes on the counted planktonic groups were rather low. This study implies that the undetected sources (detritus) comprise a great part of the food.

\section{Discussion}

The fatty acid profiles of storage lipids, triacylglycerols or wax esters have widely been used to elucidate trophic interactions of various copepod species in both marine and freshwater ecosystems (Persson and Vrede 2006; Kattner et al. 2007; Caramujo et al. 2008). The combination of fatty acid trophic markers (FATM) and stable isotopes has proven useful in deciphering trophic relations among various plankton and benthos groups (Rooker et al. 2006; Gladyshev 2009), including calanoid copepods (El-Sabaawi et al. 2009). However, published data on brackish water species of calanoid copepods and FATM in their tissues are extremely scarce (Guerrero et al. 2007). Our data confirm the results of Guerrero et al. 2007 that brackish water species of calanoids accumulate large quantities of TAG, but not wax esters, in contrast to most marine calanoid species. Hence, we used fatty acid composition of TAG to investigate food sources of Arctodiaptomus salinus in lakes Shira and Shunet.

FATM in TAG and feeding experiments as indicators of the diet of copepods

Use of FATM can provide reliable information on assimilated food, although the interpretation of the food sources is possible only at the level of large taxonomic groups. Moreover, FA footprints of some higher taxa, for instance, of green algae and Cyanobacteria or of diatoms and Gram-positive bacteria (including phototrophic purple bacteria), are quite similar. Therefore, a deeper understanding of trophic relations can be achieved if FATM analyses are supplemented with information on microplankton in seston and data from feeding experiments. We want to explore the trophic relationship of A. salinus based on known FATM for different microplankton groups and using information on species composition of lake seston and the results from feeding experiments (see data in Table 5). 
Fig. 5 Average FA levels (\% of the total) in total lipids of A. salinus, inhabiting epilimnion $(0-5 \mathrm{~m}, n=6)$ and hypolimnion $(7-10 \mathrm{~m}$, $n=6)$ of Shira lake

(Khakasia, Russia) in 20042005. Note that there were no statistically significant differences for any FA after Student's $t$-test (minimal $P=0.072$ )

Fig. 6 Average essential PUFA's levels (\% of the total) in total lipids of seston and A. salinus in Shira and Shunet lakes (Khakasia, Russia), 20042005. See text for details
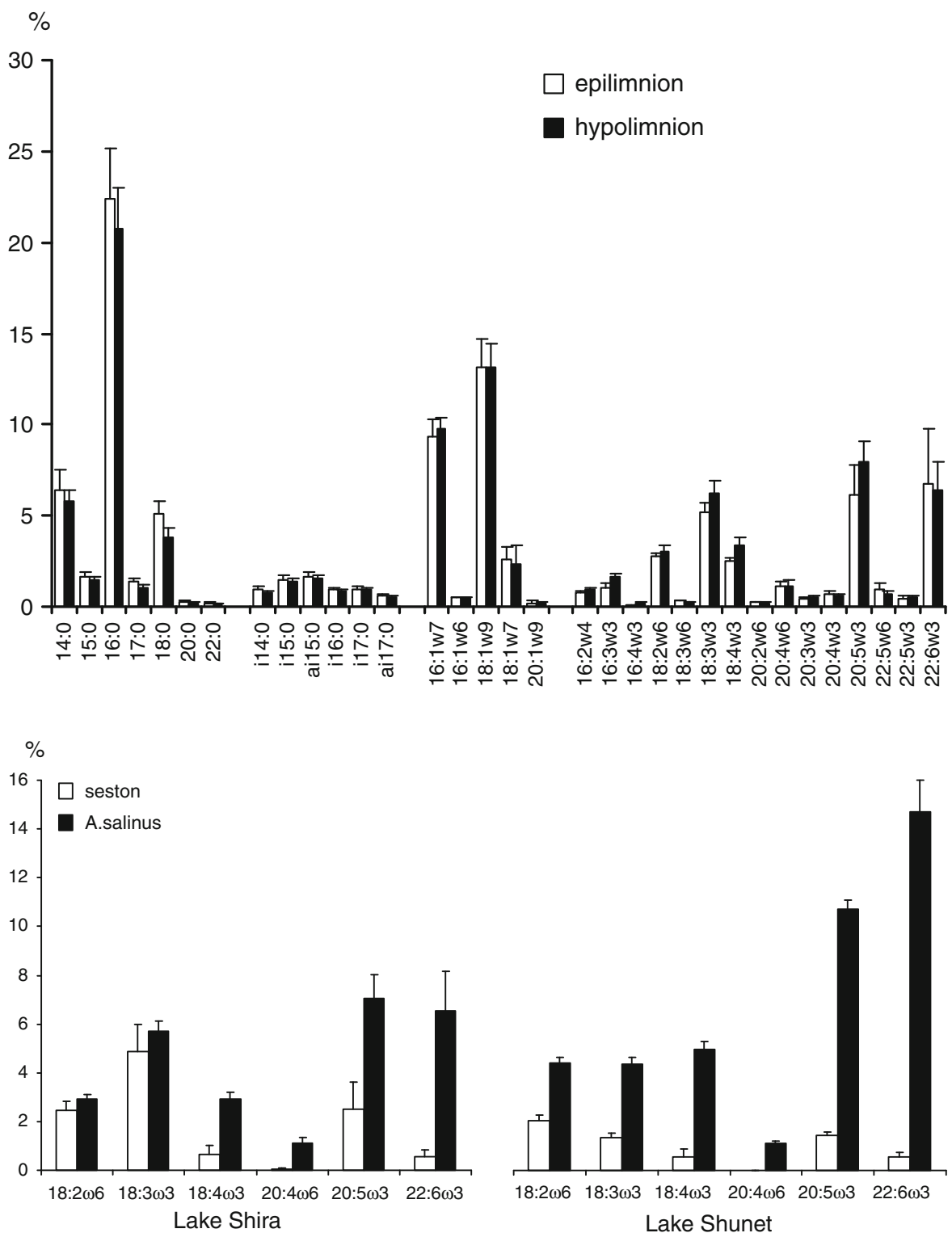

Seston of Lake Shira had the increased levels of two fatty acids, 18:3 $\omega 3$ and 16:3 103 . These FAs are typically synthesized by green algae (Thompson, 1996) and have been used as green alga markers in a freshwater lake (Leveille et al. 1997). However, it is known that $18: 3 \omega 3$ is also synthesized by Cyanobacteria, especially filamentous species (Gugger et al. 2002). Moreover, Sushchik et al. (2003a) have shown in a freshwater reservoir that 18:3 $\omega 3$ indicates dominance of both green algae and Cyanobacteria. We have noted that in summer period Cyanobacteria Lyngbya contorta, a non-identified small-sized cyanobacterial species, and green algae of Dictyospherium genus dominate phytoplankton in Lake Shira (Gaevsky et al. 2002). Green alga Botryococcus sp. usually develops in littoral part and moves to open water, while it can easily be distinguished due to highly specific fatty acid composition (Kalacheva et al. 2002). Hence, higher levels of 16:3 13 in Lake Shira were likely provided by green algae, while both greens and Cyanobacteria might be responsible for the increased levels of 18: 13 . During this investigation, feeding experiments supported the consumption of colonial Cyanobacterium Aphonothece sp. in Lake 
Shira (Tables 4, 5). We also observed earlier in similar feeding experiments in Lake Shira (Tolomeyev 2002) that A. salinus feeds on another Cyanobacterium, Lyngbya contorta, and dominant green algae, D. tetrachotomum.

In Lake Shunet, FATM 16:3 13 in seston was scarce (Fig. 4). Generally, it corresponded to the species composition, where green algae represented by $D$. tetrachotomum were $<10 \%$ of total phytoplankton biomass (Degermendzhy et al. 2003). Thus, $18: 3 \omega 3$ found in seston seems to have its origin from cyanobacterial picoplankton. This fatty acid is also found in TAG of A. salinus. However, laboratory experiments demonstrated inability of animals to feed on cyanobacterial picoplankton obviously due to the small size of cells. Thus, this fatty acid $(18: 3 \omega 3)$ in TAG of A. salinus must have its origin from other microorganisms in Lake Shunet.

Fatty acids 14:0 and 16:1 $\omega 7$ can be used as markers of diatom summer populations. Commonly, $20: 5 \omega 3$ and $\omega 7, \omega 4$ and $\omega 1$ C16 PUFAs are considered as diatom markers (Brett et al. 2009). However, Sushchik et al. (2004) have demonstrated that summer diatom populations can be low in PUFA compared with the spring ones, while 14:0 and 16:1 $\omega 7$ together are good predictors of both summer and spring populations of diatoms (Sushchik et al. 2003a). Diatoms are reported in both lakes in summer (Gaevsky et al. 2002), with lower occurrence in L. Shira, that is in good accord with the lower percentages of FATM 14:0 and 16:1 107 , observed in our study. The poor contribution of summer diatoms to the daily ration of A. salinus in L. Shira is also supported by the feeding experiments in an earlier study (Tolomeyev 2002), which shows that the only diatom species, Cyclotella tuberculata, in Lake Shira is excluded from the ration of A. salinus.

We also observed A. salinus in Lake Shira to contain more branched C14-17 and odd-numbered straight $\mathrm{C} 15$ and $\mathrm{C} 17$ acids (Fig. 7) that are commonly accepted as FATM of heterotrophic Grampositive bacteria that form the "microbial loop" (e.g., Ederington et al. 1995; Stevens et al. 2004). However, it is quite doubtful that Arctodiaptomus can effectively filter bacterioplankton (Kleppel 1993). It is very likely that such markers come from another food pathway for the calanoid, i.e. via the bacteria associated with detritus or via protozoa organisms feeding on bacteria. It is, however, interesting that in our experiments A. salinus did not graze upon small cells of picoplankton, but instead it showed in both lakes a strong preference in consuming ciliates present in the food suspension (Table 4). Moreover, our study supports some earlier studies, which
Fig. 7 Average FA levels (\% of the total) in triacylglycerols of A. salinus, inhabiting Lake Shira $(n=12)$ and Lake Shunet $(n=8)$ (Khakasia, Russia) in 2004-2005. Statistically significant differences between the means after Student's $t$-test: * $P<0.05$; ${ }^{\#} P<0.01$;

$+P<0.001$

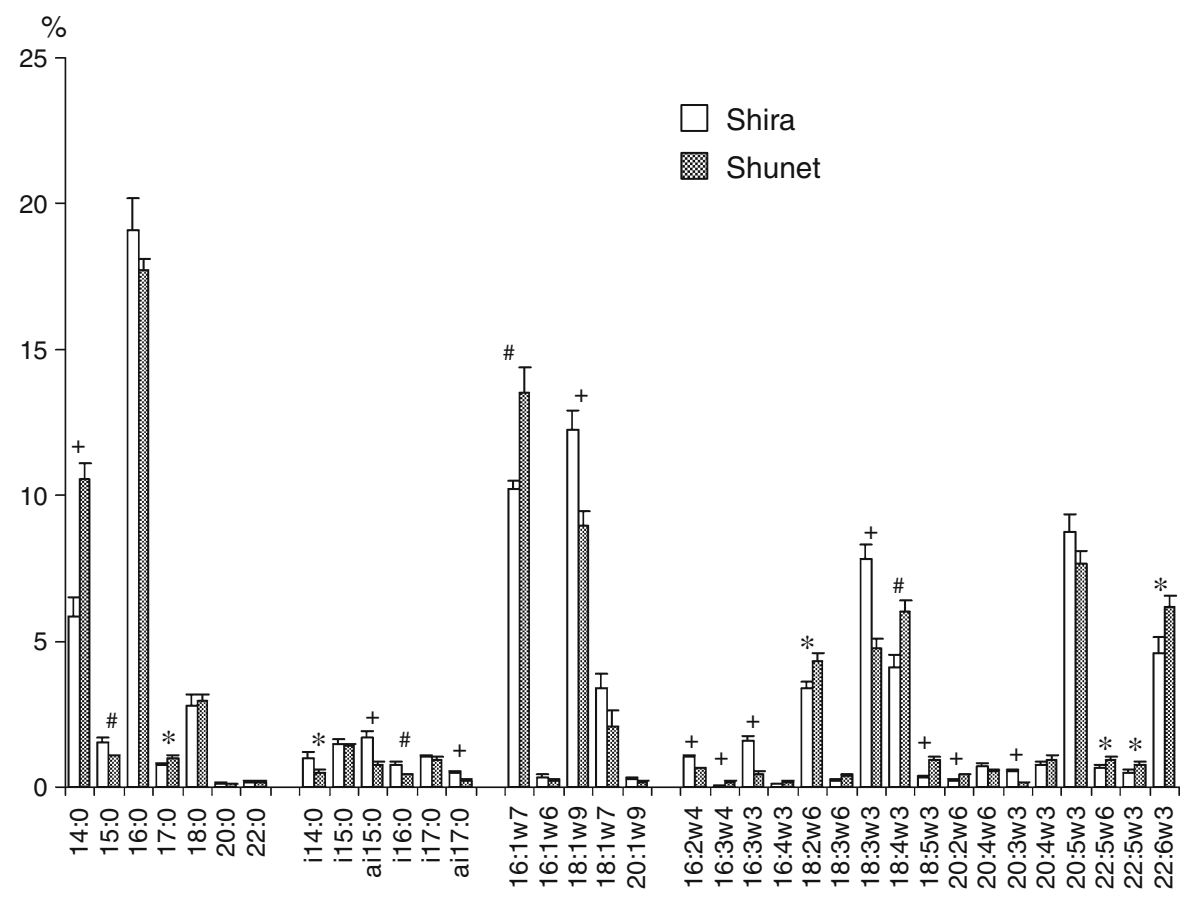




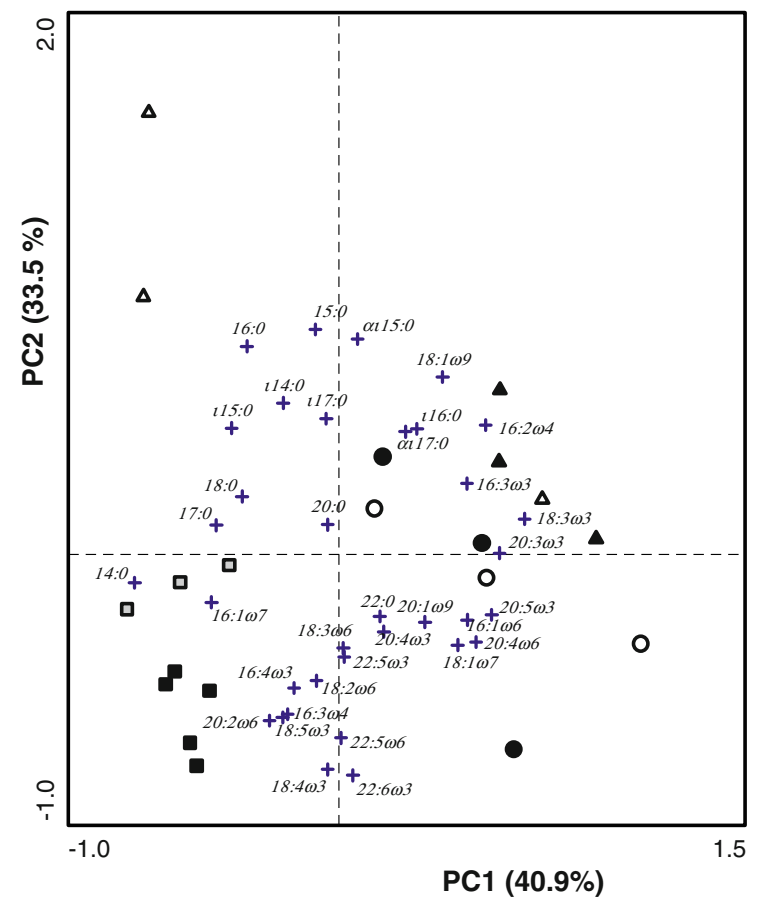

Fig. 8 PCA distance biplot showing similarity of the samples of Arctodiaptomus salinus varied within Shira and Shunet lakes, years $(2004,2005)$ and ecological zones. The length of the FA vectors (not drawn, but arrows connecting the origin with the FA cross-marks) reflect the contribution of FA to the ordination subspace definition. Lake Shunet: $\square$ - 2004, $\mathbf{0}$ - 2005. Lake Shira: $\triangle$ - epilimnion zone and $\boldsymbol{\Delta}$ - hypolimnion zone, 2004; $\bigcirc$ - epilimnion zone and; - hypolimnion zone, 2005

document feeding on ciliates by the calanoid copepods, in both freshwater (e.g., Desvilettes et al. 1997; Kagami et al. 2002) and marine ecosystems (Ederington et al. 1995). Notably, levels of bacterial FATM in the samples of L. Shira were quite high and varied greatly both spatially and temporally (Fig. 8).

The sestonic fatty acids are vertically highly stratified (Fig. 3), depending on the depth distribution of different algae, bacteria and protozoa taxa that contain these acids (Kopylov et al. 2002; Gaevsky et al. 2002). In contrast, the FATM in the copepods from epilimnion and hypolimnion of L. Shira are similar so that we can assume that the grazer population of $A$. salinus actively migrate to certain specific depths and feed on the particular plankton species or detritus. Both foraging migration and diel vertical migration of zooplankton are widely reported in natural ecosystems, the latter as an avoidance reaction to the visual predation by fish (Lampert et al. 2003). However, in the absence of fish in both lakes, we can safely assume that the migration of calanoids in our saline lakes must be triggered by factors other than predation. Thus, foraging migration is the main explanation for vertical movements of A. salinus in these two lakes. For Lake Shira, it should be emphasized that fatty acids 18:3 $\omega 3,20: 5 \omega 3$ and 22:6 63 all of which were abundant in TAG of $A$. salinus from both epilimnion and hypolimnion zones were primarily detected only in hypolimnion seston (Fig. 3; Table 1). Thus, the epilimnion population of A. salinus must migrate to these deeper waters to maintain in their bodies the observed levels of these acids. This argument, however, is not supported by Tolomeyev and Zadereev (2005) who found that diel vertical migration of $A$. salinus in Lake Shira is weakly pronounced due to the absence of predators for zooplankton. Nevertheless, the difference between day and nighttime distribution profiles of A. salinus does comprise its lower day-time density in the upper $(1 \mathrm{~m})$ layer probably due to a negative phototactic response to intensive solar radiation. Moreover, the absence of a pronounced diel descent to deeper layers does not rule out a non-synchronous migration. A non-synchronous migration might be caused by physiological conditions of individuals. Apparently, physiological deficiency of essential acids $18: 3 \omega 3,20: 5 \omega 3$ and $22: 6 \omega 3$ in A. salinus bodies could act as a trigger for individuals in epilimnion to descend into hypolimnion in pursuit of high-quality food sources.

In addition to the higher levels of FATM of diatoms, the population of A. salinus in Lake Shunet had significantly higher percentages of 18:4 $\omega 3$, 18:5 03 and C 22 polyenoic acids in TAG (Figs. 7, 8 ), which can be considered as markers of organic matter originated from autotrophic flagellates (Desvilettes et al. 1997). This group also contains high levels of 18:3 $\omega 3$ that can explain the relatively higher content of this acid (18:3) in the animals' bodies than in seston (Fig. 7). As already discussed, A. salinus seems to have limited opportunities to acquire 18:3 $\omega 3$ from scarce green algae or difficult to filter plankton such as cyanobacterial picoplankton in Lake Shunet.

Fatty acid $18: 5 \omega 3$ is known to be synthesized by dinoflagellates and is used as their FATM if found in zooplankton (Napolitano 1999). Another likely source of its occurrence in zooplankton is retroconversion of $\omega 3 \mathrm{C} 20$ PUFA, i.e. shortening of a FA 
Table 4 Mean concentrations of phytoplankton and protozoa species in the control $(N \mathrm{c})$ and experimental $(\mathrm{Ne})$ collecting vessels in the experiments on Arctodiaptomus salinus feeding conducted by flow-through method

\begin{tabular}{|c|c|c|c|c|c|c|}
\hline \multirow[t]{2}{*}{$\begin{array}{l}\text { Phytoplankton and protozoa } \\
\text { species in seston }\end{array}$} & \multirow[t]{2}{*}{$\begin{array}{l}\text { Weight of a } \\
\text { cell }\left(\cdot 10^{-12} \mathrm{~g}\right)\end{array}$} & \multicolumn{2}{|c|}{$\begin{array}{l}\text { Concentrations in the collecting vessels } \\
\left(\cdot 10^{3} \pm \mathrm{SE} \text {, cells } \mathrm{ml}^{-1}, n=3\right)\end{array}$} & \multirow[t]{2}{*}{$T$} & \multirow[t]{2}{*}{$P$} & \multirow[t]{2}{*}{$R \pm \mathrm{SE}(\%)$} \\
\hline & & $N c$ (without animals) & Ne (with animals) & & & \\
\hline \multicolumn{7}{|l|}{ Lake Shira } \\
\hline Aphanothece sp. (colonial) & 1.36 & $67.5 \pm 12.7$ & $16.0 \pm 8.2$ & 18.4 & $0.002 *$ & $0.4 \pm 0.03$ \\
\hline Lyngbia contorta & 2.25 & $114.1 \pm 34.9$ & $131.8 \pm 24.5$ & 1.20 & 0.265 & - \\
\hline Unicellular pico cyanobacteria & 0.52 & $616.4 \pm 127.1$ & $708.5 \pm 120.1$ & 1.8 & 0.102 & - \\
\hline Strombidium spp. & 1,000 & $0.052 \pm 0.110$ & 0 & 1.42 & 0.193 & $0.03 \pm 0.03$ \\
\hline Cyclidium spp. & 2,000 & $0.045 \pm 0.070$ & 0 & 1.92 & 0.092 & $0.02 \pm 0.02$ \\
\hline Heterotrophic nanoflagellates & 80 & $0.295 \pm 0.162$ & $0.179 \pm 0.314$ & 1.08 & 0.311 & - \\
\hline \multicolumn{7}{|l|}{ Lake Shunet } \\
\hline Sulfur purple bacteria & 4.19 & $793.5 \pm 157.7$ & $193.0 \pm 80.3$ & 19.03 & $0.000 *$ & $18.7 \pm 0.02$ \\
\hline Synechocystis sp. & 0.52 & $762.4 \pm 32.0$ & $653.8 \pm 98.4$ & 2.02 & 0.078 & - \\
\hline Cryptomonas salina & 600 & $1.909 \pm 0.806$ & $0.568 \pm 0.130$ & 4.35 & $0.002 *$ & $6.2 \pm 2.05$ \\
\hline Cyclidium spp. & 2,000 & $0.070 \pm 0.015$ & 0 & 11.07 & $0.000 *$ & $1.0 \pm 0.01$ \\
\hline Strombidium spp. & 57,000 & $0.085 \pm 0.062$ & 0 & 3.33 & 0.020 & $38.2 \pm 5.31$ \\
\hline Heterotrophic nanoflagellates & 100 & $0.079 \pm 0.003$ & $0.125 \pm 0.117$ & 1.20 & 0.264 & - \\
\hline
\end{tabular}

Significant decrease in density in experimental collecting vessels compared to the control ones supported the consumption. The significance was estimated by paired $t$-test. Asterisk indicated $95 \%$ level. Daily rations ( $R, \%$ of the body wet weight) for the consumed species (or groups) were calculated

carbon chain in two carbon atoms (Von Elert 2002). There could be two explanations for A. salinus in L. Shunet having unusually high levels of 18:5 13 (ca. $1 \%$ ) in TAG. First, A. salinus in L. Shunet might derive this acid together with C22 $\omega 3$ PUFAs from Cryptomonas salina, a flagellate which is highly concentrated in relatively thin layer adjacent to chemocline near lake bottom (Khromechek et al. this volume). Interestingly, we did not find this FATM in any of pelagic seston samples from our two lakes. We took samples from the middle of the water column, while the autotrophic and heterotrophic flagellates mostly inhabited the specific thin layer near bottom. Finding these FA in the copepod tissues confirms the speculation on their non-synchronous individual migrations and feeding on flagellates in this layer. The highly selective feeding of the Arctodiaptomus populations on $C$. salina is also confirmed in this laboratory study. In addition, the calanoid population of L. Shunet showed higher content of linoleic acid in TAG, which some authors (El-Saabawi et al. 2009) relate with feeding on dinoflagellates in copepods. A second explanation of unusually high levels of
18:5 03 in Arctodiaptomus TAG is that the significantly higher content of DHA of total lipids in L. Shunet's copepod populations (Fig. 6) might result in more active retroconversion and accumulation of 18:5 13 in TAG of A. salinus in L. Shunet. However, as the physiological importance of DHA and other long-chain PUFA is very high, their retroconversion in $18: 5 \omega 3$ is unlikely.

Essential PUFAs of Arctodiaptomus as a result of physiological adaptation to the lake conditions

Fatty acid trophic markers and the feeding experiments, together, indicate that nutritional spectra of the calanoid populations inhabiting the two neighboring brackish lakes differ partly due to different composition of lakes' seston (Table 5). However, the two Arctodiaptomus populations markedly differed in levels of essential long-chain PUFA, EPA and DHA, although the levels of these FA in seston in both lakes were quite similar (Fig. 6). In general, both the grazer populations were highly enriched in the essential $\omega 3$ PUFA, but more so in L. Shunet, compared with 


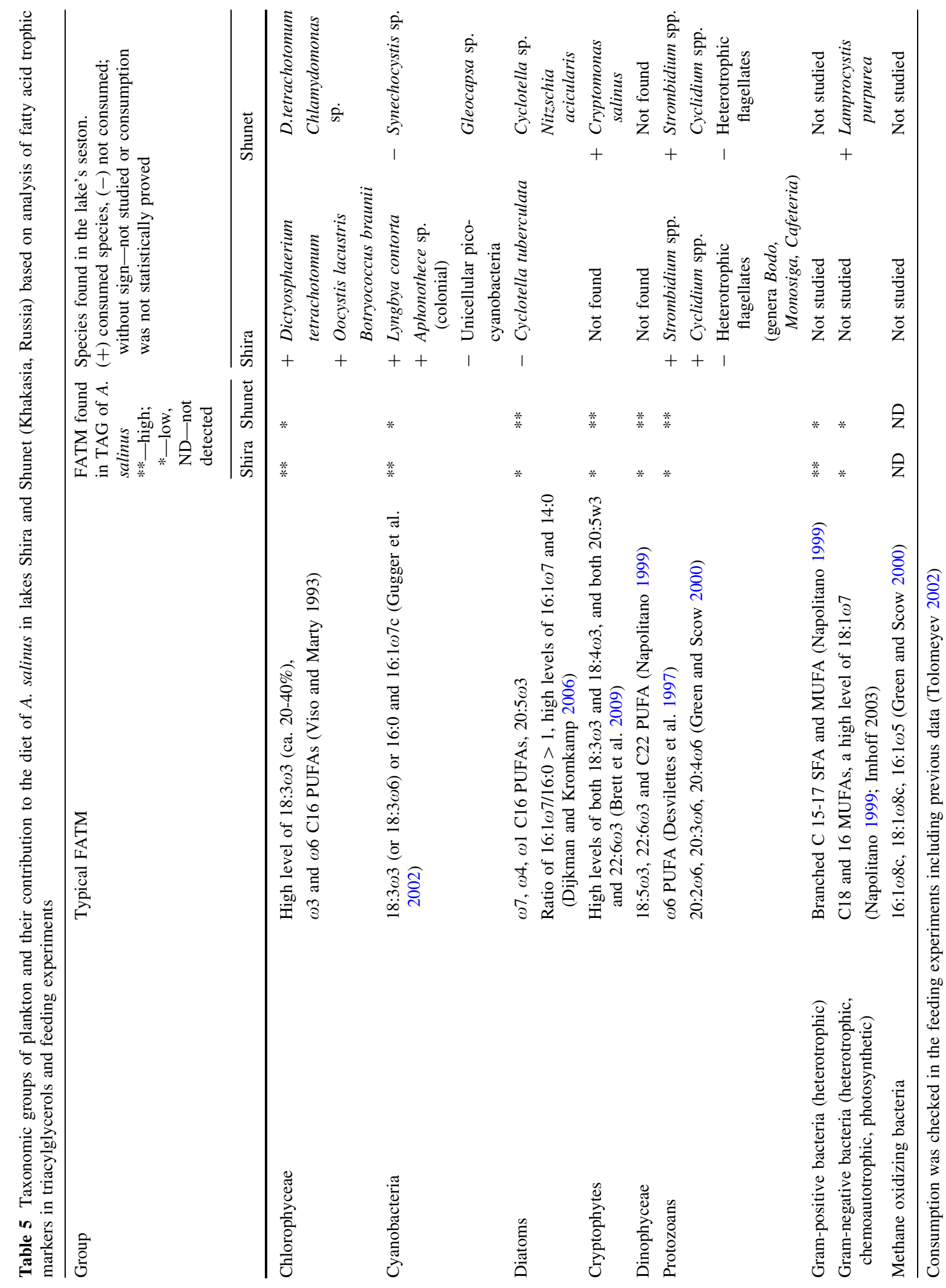


these fatty acids in seston. This higher enrichment of the diaptomid population in L. Shunet could be an adaptive response to higher salinity levels in the near bottom layer in the lake.

Note that differences in feeding spectra of populations of A. salinus in two lakes revealed by FATM in storage lipids and the experiments mirror the FA composition of total lipids, principally in $\omega 3$ longchain PUFA (Fig. 6). This is not surprising because total lipids of the animals comprise greater part of TAG (Fig. 1). However, the distribution of the PUFAs of key physiological importance, i.e. EPA and DHA in different lipid fractions, differs between L. Shira and L. Shunet populations. Whereas the percentages of EPA and DHA in total lipids and TAG are similar in L. Shira's population, they are markedly higher in total lipids in L. Shunet animals than the FA in TAG fraction. Certainly, in L. Shunet, the bulk of long-chain PUFA in the calanoids originates from polar lipids, the structural components of cell membranes. Thus, we can speculate about the accumulation of long-chain $\omega 3$ PUFAs in polar lipids of A. salinus in L. Shunet. Probably, the plankton community comprised of dinoflagellates, cryptophytes and diatoms, inhabiting the layers adjacent to chemocline in the lake, provides the copepods with the essential $\omega 3$ PUFA (18:4 $\omega 3, \quad 20: 5 \omega 3$ and 22:6 $\omega 3$ ).

The ability of various species of copepods to synthesize EPA and DHA from C18 PUFA as well as their ability to biochemically convert EPA into DHA is still very controversial. For instance, according to Caramujo et al. (2008) harpacticoid copepods can convert short-chain precursors into long-chain and more unsaturated EPA and DHA; also Persson and Vrede (2006) provide a similar indirect evidence for several plankton freshwater calanoids. On the other hand, Bell et al. (2007) show that four marine calanoid species possess little capacity to convert 18:3 $\omega 3$ into C20-22 PUFA. We too could not conclude from our data whether the population of A. salinus in L. Shunet has a greater capacity to synthesize DHA and EPA from the food precursors than its population in L. Shira. Meanwhile, it is unlikely that two genetically and geographically close populations of the calanoid under study significantly differ in their ability to synthesize DHA and EPA. We suggest that higher DHA and EPA levels in the membrane structural lipids of L. Shunet's population result from their specific retention from food sources and their subsequent accumulation in animal's tissues.

The increased levels of DHA and EPA of the copepods in L. Shunet might also be related to adaptation of the population to significantly higher salinity in chemocline layer. Salinity of water column in L. Shunet is about $14 \mathrm{~g}^{-1}$ in upper layers, but near chemocline zone it increases sharply to $40 \mathrm{l}^{-1}$ at $5 \mathrm{~m}$ depth. The changes in PUFA percentages seem to be involved in the osmoregulation of crustaceans through modulation of $\mathrm{Na}^{+} / \mathrm{K}^{+}$-ATPase activity and (or) direct membrane permeability to water and ions as reported by Palacios and Racotta (2007). Although the effect of salinity on fatty acid composition of aquatic animals is far from clear, there is evidence that membrane lipids in the freshwater environment should contain more saturated acids to prevent more intensive loss of various salt ions in comparison with that in saline waters. This is in accord with the observation of generally lower PUFA content, especially of $\omega 3$ family, in freshwater than in marine fish (Ahlgren et al. 1994). Evidently, the copepods do not stay continuously in the relatively high-salinity deep layer, even though they must tolerate chemical conditions prevailing here while they feed on specific community there.

\section{Conclusion}

Combined use of FATM approach and direct feeding experiments revealed that the differences of feeding spectra A. salinus were driven by both different seston FA composition and selective feeding. In Lake Shira, Arctodiaptomus salinus preferably consumed green algae, Cyanobacteria and heterotrophic bacteria. In L. Shunet, feeding spectra of this calanoid copepod comprised diatoms, cryptophytes, purple bacteria and ciliates. In addition to the different feeding spectra, the two Arctodiaptomus populations markedly differed in their body levels of essential long-chain PUFA, EPA and DHA. We presume that this difference is partly explained by FA composition of consumed food and the necessity to adapt to specific physico-chemical conditions of the lakes. The higher levels of the essential $\omega 3$ PUFA in $A$. salinus in Lake Shunet could be considered as an adaptive response of the animals to a higher salinity 
level in the chemocline zone where food levels are high. Thus, the chemocline zone of L. Shunet seems to play an important role in life strategy of the copepods dually controlling their fatty acid composition-through both the specific food sources and the specific higher salinity condition.

Acknowledgments The work was performed using GS-MS of Joint Equipment Unit of Krasnoyarsk Scientific Centre of Siberian Branch of Russian Academy of Sciences. Financial support was provided by NWO project no. 047.017.012 (The Netherlands), Grants No. RUX0-002-KR-06 and PG07-002-1 of the US Civilian Research \& Development Foundation for the Independent States of the Former Soviet Union (CRDF) and the Ministry of Education and Sciences of Russian Federation; grants of Russian Foundation for Basic Research (RFBR): No. 08-04-01232, 09-04-98042, 09-04-98036. The work was partially supported by Integration project of SB RAS No. 95. We thank Dr. Elena Khromechek for the help with the identification and counting of microorganisms in the feeding experiments. We also acknowledge four anonymous reviewers for their helpful comments on the manuscript.

\section{References}

Ahlgren G, Blomqvist P, Boberg M, Gustafsson I-B (1994) Fatty acid content of the dorsal muscle-an indicator of fat quality in freshwater fish. J Fish Biol 45:131-157

Bell MV, Dick JR, Anderson TA, Pond DW (2007) Application of liposome and stable isotope tracer techniques to study polyunsaturated fatty acid biosynthesis in marine zooplankton. J Plankton Res 5:417-422

Bern L (1994) Particle selection over a broad size range by crustacean zooplankton. Freshw Biol 32(1):105-112

Bourder GG, Amblard CA (1989) Lipids in Acanthodiaptomus denticornis during starvation and fed on three algae. J Plankton Res 11:1201-1212

Brett MT, Muller-Navarra DC, Ballantyne AP, Ravet JL, Goldman CR (2006) Daphnia fatty acid composition reflects that of their diet. Limnol Oceanogr 51:2428-2437

Brett MT, Muller-Navarra DC, Persson J (2009) Crustacean zooplankton fatty acid composition. In: Arts MT, Brett MT, Kainz M (eds) Lipids in aquatic ecosystems. Springer, New York, pp 115-146

Caramujo M-J, Boschker HTS, Admiraal W (2008) Fatty acid profiles of algae mark the development and composition of harpacticoid copepods. Freshw Biol 53:77-90

Degermendzhy AG, Gulati RD (2002) Understanding the mechanisms of blooming of phytoplankton in Lake Shira, a saline lake in Siberia (the Republic of Khakasia). Aquat Ecol 36(2):331-340

Degermendzhy AG, Gaevsky NA, Belonog NP, Rogozin DYu, Ivanova EA, Koltashev AA, Gribalev ES (2003) Study of the physico-chemical and biological characteristics of two balineological lakes (Matarak, Shunet, Repablic Khakassia). Vestnik KraSU 5:107-115 (in Russian, English abstract)
Demott WR (1991) Foraging on cyanobacteria by copepodsresponses to chemical defenses and resource abundance. Ecology 72:1820-1991

Desvilettes C, Bourdier G, Amblard C, Barth B (1997) Use of fatty acids for the assessment of zooplankton grazing on bacteria, protozoans and microalgae. Freshw Biol 38:629-637

Dijkman NA, Kromkamp JC (2006) Phospholipid-derived fatty acids as chemotaxonomic markers for phytoplankton: application for inferring phytoplankton composition. Mar Ecol Prog Ser 324:113-125

Ederington M, McManus GB, Harvey R (1995) Trophic transfer of fatty acids, sterols, and a triterpenoid alcohol between bacteria, a ciliate, and the copepod Acartia tonsa. Limnol Oceanogr 40:860-867

El-Sabaawi R, Dower JF, Kainz M, Mazumder A (2009) Characterizing dietary variability and trophic positions of coastal calanoid copepods: insight from stable isotopes and fatty acids. Mar Biol 156:225-237

Gaevsky NA, Zotina TA, Gorbaneva TB (2002) Vertical structure and photosynthetic activity of Shira Lake phytoplankton. Aquat Ecol 36:165-178

Gladyshev MI (2009) Stable isotope analyses in aquatic ecology (a review). J Sib Fed Univ Biol 2:381-402

Gladyshev MI, Temerova TA, Dubovskaya OP, Kolmakov VI, Ivanova EA (1999) Selective grazing on Cryptomonas by Ceriodaphnia quadrangula fed a natural phytoplankton assemblages. Aquat Ecol 33:347-353

Gosselain V, Hamilton P, Descy JP (2000) Estimating phytoplankton carbon from microscopic counts: an application for riverine systems. Hydrobiologia 438:75-90

Goulden CE, Place AR (1990) Fatty acid synthesis and accumulation rates in daphniids. J Exp Zool 256:168-178

Green CT, Scow KM (2000) Analysis of phospholipid fatty acids (PLFA) to characterize microbial communities in aquifers. Hydrogeol J 8:126-141

Guerrero F, Parra G, Jiménez-Gómez F, Salazar C, JiménezMelero R, Galotti A, García-Muñoz E, Lendínez ML, Ortega F (2006) Ecological studies in Alto Guadalquivir wetlands: a first step towards the application of conservation plans. Limnetica 25(1-2):95-106

Guerrero F, Jimenez-Melero R, Parra G, Lopez de la Torre MD, Melguizo M (2007) Lipid composition of Arctodiaptomus salinus (Copepoda: Calanoida). J Freshw Ecol 22(1):147-150

Gugger M, Lyra C, Suominen I, Tsitko I, Humbert J-F, Salkinoja-Salonen MS, Sivonen K (2002) Cellular fatty acids as chemotaxonomic markers of the genera Anabaena, Aphanizomenon, Microcystis, Nostoc and Planktothrix (Cyanobacteria). Int J Syst Evol Microbiol 52:1007-1015

Hagen W, Auel H (2001) Seasonal adaptations and the role of lipids in oceanic zooplankton. Zoology 104:313326

Hansen B, Bjørnsen PK, Hansen PJ (1994) The size ratio between planktonic predators and their prey. Limnol Oceanogr 39:395-403

Jersabek CD, Brancelj A, Stoch F, Schabetsberger R (2001) Distribution and ecology of copepods in mountainous regions of the Eastern Alps. Hydrobiologia 453454(1):309-324

Kagami M, Yoshida T, Gurung TB, Urabe J (2002) Direct and indirect effects of zooplankton on algal composition in in situ grazing experiments. Oecologia 133(3):356-363 
Kalacheva GS, Zhila NO, Volova TG (2002) Lipid and hydrocarbon compositions of a collection and wild sample of the green microalga Botryococcus. Aquat Ecol 36:317330

Kattner G, Hagen W, Lee RF, Campbell R, Deibel D, FalkPetersen S, Graeve M, Hansen BW, Hirche HJ, Jonasdottir SH, Madsen ML, Mayzaud P, Muller-Navarra D, Nichols PD, Paffenhofer G-A, Pond D, Saito H, Stubing D, Virtue P (2007) Perspectives on marine zooplankton lipids. Can J Fish Aquat Sci 64:1628-1639

Kleppel GS (1993) On the diet of calanoid copepods. Mar Ecol Prog Ser 99:183-195

Knisley K, Geller W (1986) Selective feeding of four zooplankton species on natural lake phytoplankton. Oecologia 69:86-94

Kopylov AI, Kosolapov DB, Degermendzhy NN, Zotina TA, Romanenko AV (2002) Phytoplankton and bacterial production and protozoan bacterivory in a stratified, brackishwater Lake Shira (Khakasia, Siberia). Aquat Ecol 36(2):205-218

Kurmayer R, Juttner F (1999) Strategies for the co-existence of zooplankton with the toxic cyanobacterium Planktothrix rubescens in Lake Zurich. J Plankton Res 21(4):659-683

Lampert W, McCauley E, Manly BFJ (2003) Trade-offs in the vertical distribution of zooplankton: deal free distribution with costs? Proc R Soc Lond B 270:765-773

Leps J, Smilauer P (2003) Multivariate analysis of ecological data using CANOCO. Cambridge University Press, Cambridge, p 282

Leveille JC, Amblard C, Bourdier G (1997) Fatty acids as specific algal markers in a natural lacustrian phytoplankton. J Plankton Res 19:469-490

Makhutova ON, Khromechek EB (2008) Fatty acids of sestonic lipid classes as a tool to study nutrition spectra of rotifers and ciliates in a Siberian eutrophic reservoir. J Sib Fed Univ Biol 1:40-59

Napolitano GE (1999) Fatty acids as trophic and chemical markers in freshwater ecosystems. In: Arts MT, Wainman BC (eds) Lipids in freshwater ecosystems. Springer, New York, pp 21-44

Overmann J, Hall KJ, Northcote TG, Beatty JT (1999) Grazing of the copepod Diaptomus connexus on purple sulfur bacteria in a meromictic salt lake. Environ Microbiol $1: 213-221$

Palacios E, Racotta IS (2007) Salinity stress test and its relation to future performance and different physiological responses in shrimp postlarvae. Aquaculture 268:123-135

Persson J, Vrede T (2006) Polyunsaturated fatty acids in zooplankton: variation due to taxonomy and trophic position. Freshw Biol 51:887-900

Porter KG (1975) Viable gut passage of gelatinous green algae ingested by Daphnia. Verh Int Ver Theor Angew Limnol 19:2840-2850

Quesada A, Juttner F, Zotina T, Tolomeyev A, Degermendzhy A (2002) Heterotrophic capability of a metalimnetic plankton population on saline Lake Shira (Siberia, Khakasia). Aquat Ecol 36(2):219-227

Rogozin DY, Pimenov NV, Kosolapov DB, Chan'kovskaya YV, Degermendzhy AG (2005) Thin-layer vertical distributions of purple sulfur bacteria in chemocline zones of meromictic lakes Shira and Shunet (Khakassia). Dokl Biol Sci 400 (1-6):54-56

Rooker JR, Turner JP, Holt SA (2006) Trophic ecology of Sargassum-associated fishes in the Gulf of Mexico determined from stable isotopes and fatty acids. Mar Ecol Prog Ser 313:249-259

Smyntek PM, Teece MA, Schulz KL, Storch AJ (2008) Taxonomic differences in the essential fatty acid composition of groups of freshwater zooplankton relate to reproductive demands and generation time. Freshw Biol 53:1768-1782

Sommer U, Sommer F (2006) Cladocerans versus copepods: the cause of contrasting top-down controls on freshwater and marine phytoplankton. Oecologia 147:183-194

Sommer U, Stibor H (2002) Copepoda-Cladocera-Tunicata: the role of three major mesozooplankton groups in pelagic food webs. Ecol Res 17:161-174

Stevens CJ, Deibel D, Parrish CC (2004) Species-specific differences in lipid composition and omnivory indices in Arctic copepods collected in deep water during autumn (North Water Polynya). Mar Biol 144:905-915

Sushchik NN, Gladyshev MI, Kalachova GS, Kravchuk ES, Dubovskaya OP, Ivanova EA (2003a) Particulate fatty acids in two small Siberian reservoirs dominated by different groups of phytoplankton. Freshw Biol 48:394-403

Sushchik NN, Gladyshev MI, Moskvichova AV, Makhutova ON, Kalachova GS (2003b) Comparison of fatty acid composition in major lipid classes of the dominant benthic invertebrates of the Yenisei River. Comp Biochem Physiol B134:111-122

Sushchik NN, Gladyshev MI, Makhutova ON, Kalachova GS, Kravchuk ES, Ivanova EA (2004) Associating particulate essential fatty acids of the $\omega 3$ family with phytoplankton species composition in a Siberian reservoir. Freshw Biol 49:1206-1219

Swadling KM, Gibson JAE, Pienitz R, Vincent WF (2001) Biogeography of copepods in lakes and ponds of subarctic Québec, Canada. Hydrobiologia 453-454(1):341-350

Thompson GA (1996) Lipids and membrane function in green algae. Biochim Biophys Acta 1302:17-45

Tolomeyev AP (2002) Phytoplankton diet of Arctodiaptomus salinus (Copepoda, Calanoida) in Shira Lake (Khakasia). Aquat Ecol 36(2):229-234

Tolomeyev AP, Zadereev YeS (2005) An in situ method for the investigation of vertical distributions of zooplankton in lakes: test of a two-compartment enclosure. Aquat Ecol 39:181-188

Torke B (2001) The distribution of calanoid copepods in the plankton of Wisconsin Lakes. Hydrobiologia 453454(1):351-365

Von Elert E (2002) Determination of limiting polyunsaturated fatty acids in Daphnia galeata using a new method to enrich food algae with single fatty acids. Limnol Oceanogr 47:1764-1773

Wen Z, Zhi-hui H (1999) Biological and ecological features of inland saline waters in North Hebei, China. Int J Salt Lake Res 8(3):267-285

Zadereev YS, Tolomeyev AP (2007) The vertical distribution of zooplankton in brackish meromictic lake with deepwater chlorophyll maximum. Hydrobiologia 576:69-82 